Proceedings of the New Zealand Grassland Association, 47: 135-139 (1986)

\title{
SUMMER DROUGHTS IN NORTHLAND A POOR EXCUSE
}

\author{
G. J. FERRIER \\ N.Z. Dairy Board Consulting Officer,
}

Kerikeri.

\section{INTRODUCTION}

Dry summer conditions in Northland have been cited as a significant limiting factor for high levels of milkfat production. For example: "Droughts of significant economic impact on the agricultural economy occur on average once in every three years" (Male 1978). "Dairy farming is a major part of Northland agriculture but the climate is not very suitable for dairy production . and droughts from January/February to April are not uncommon" (M.A.F. 1980).

At other times though, Northland has been described quite differently, du Faur (1962) wrote: "Some districts such as South Auckland, parts of the Waikato, Manawatu, Wairarapa _ will benefit from the provision of (summer) supplementary feed in a majority of seasons. Other areas such as Bay of Plenty, North Auckland . rarely need summer supplementary feeding".

So it woud seem that Northland has a real Jekyll and Hyde character. Despite the different views, over 2000 farmers find dairy farming to be the most economic land use. Northland produces around 13\% of New Zealand's annual dairy export earnings. It is in fact, a larger dairy production area than either the Bay of Plenty, Manawatu/Wairarapa or the South Island. Today the industry in Northland is stronger than ever.

This paper examines the "summer drought" view of Northland by comparing production trends with the South Auckland (Waikato) region the "Mecca" of New Zealand's dairy industry.

\section{DROUGHT FREQUENCY}

Droughts generally have been defined by reference to meterological data (de Lisle and Kerr 1964, Coulter 1965, Martin and Waugh 1971). However, this approach makes no allowance for the influence of management, which can significantly modify the effects of climatic extremes.

Fig. 1 shows the annual total production for a Northland dairy farm that has had consistent area, stock numbers and good management for the last 15 years. The farm is on a light "drought-prone" soil type. Severe drops in production occur every five years approximately. Each of these "severe" droughts is preceded by a "sensitizing" dry summer thatdepletes reserves of supplements and lightens stock condition. A similar effect was noted by Scott (1980), in the South Auckland area.

Fig. 2 shows the annual total milkfat production for Northland and South Auckland for the last 25 years. The variations from season to season are remarkably similar for both regions (N.Z. Dairy Board, Farm Production Reports). Perhaps the most significant trend is the diversion in production since the early 1970's. This trend is highlighted even more in Fig. 3 and by Table 1 which show production per cow under herd testing for both regions over the same period (N.Z. Dairy Board, opc. cit.).

So it would appear, that for some reason, Northland is gradually slipping behind the South Auckland region. To try to define this difference more closely, Table 2 shows the seasonal distribution of production for blocks of five seasons. These periods contain no obvious drought years and could therefore be considered the "normal" for both regions. The annual production has been split into two periods, 1) up to 31 


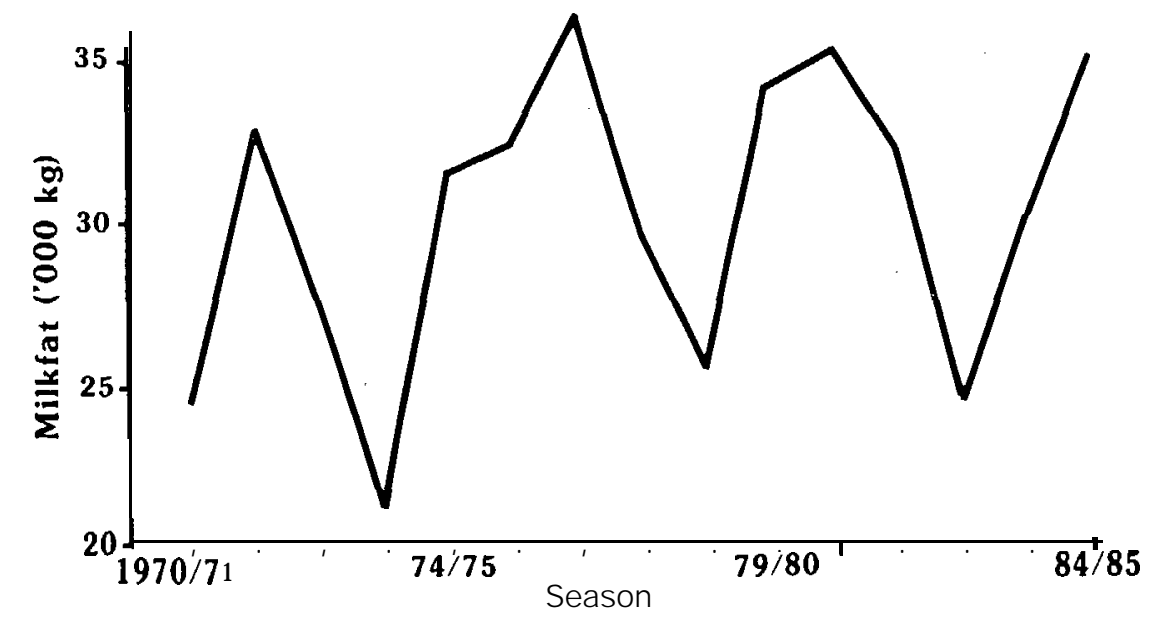

FIGURE 1: Yearly Production on a 'top' Northland dairy farm.

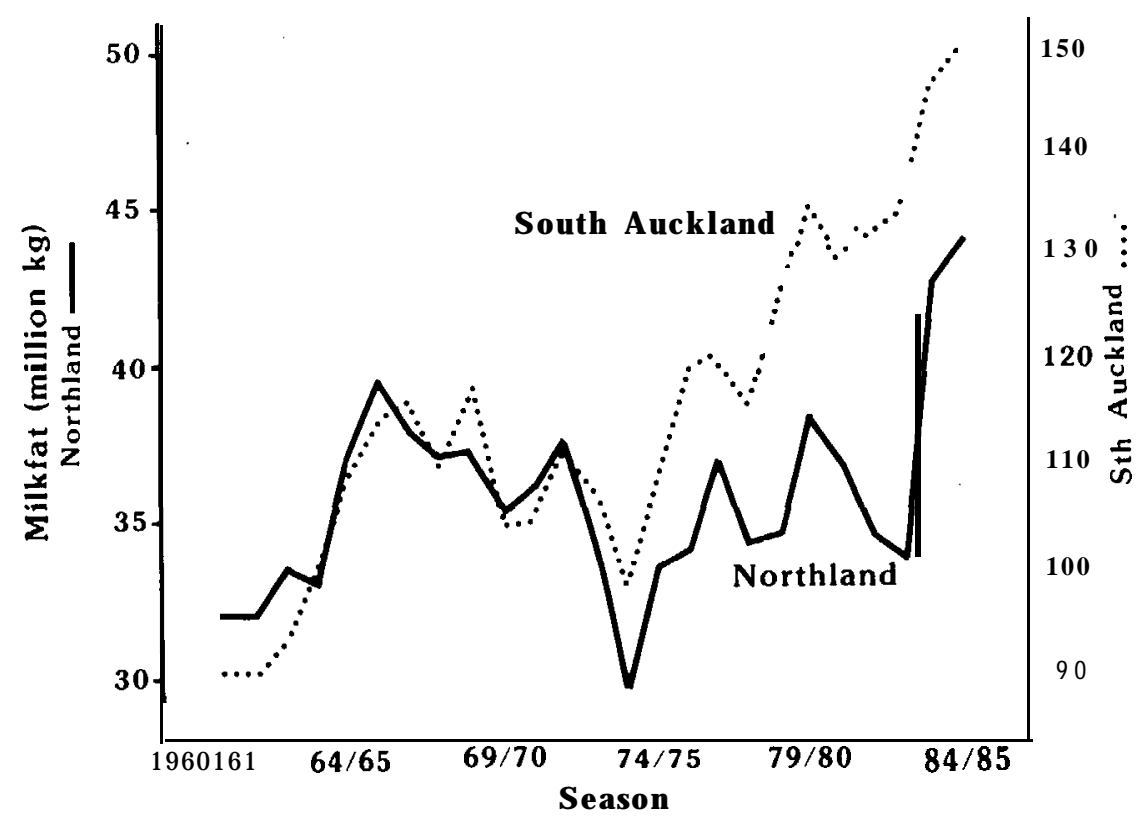

FIGURE 2: A comparison of total milkfat production between Northland and South Auckland. 


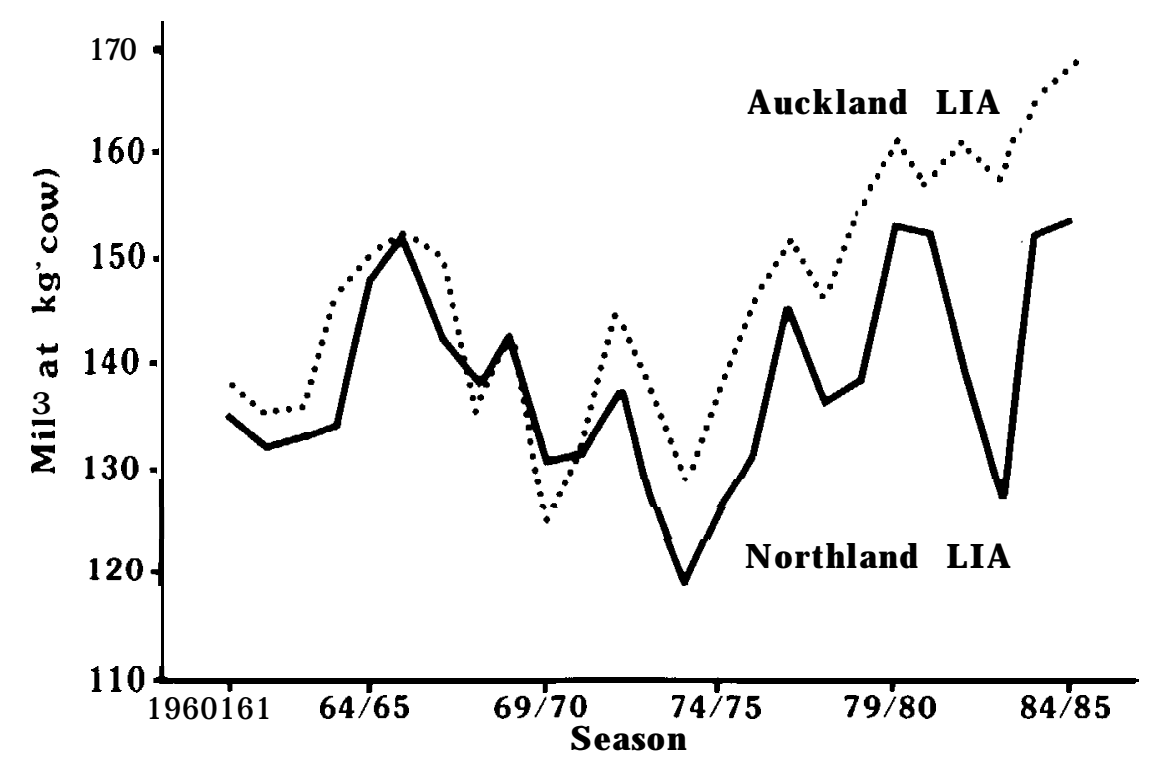

FIGURE 3: Milkfat production per cow herd tested.

TABLE 1: Milkfat production per cow herd tested. (kg/cow)

\begin{tabular}{l|ccccc|}
\hline & $1960-65$ & $1966-70$ & $1971-75$ & $1976-80$ & $1981-85$ \\
\cline { 2 - 6 } Auckland LIA & 141 & 141 & 136 & 152 & 162 \\
Northland LIA & 137 & 141 & 128 & 141 & 144 \\
\hline Difference (A-N) & 4 & & 8 & 11 & 18 \\
\hline
\end{tabular}

TABLE 2: Seasonal distribution of production (kg/cow). (Spring calving to 31 December; Summer 1 January to end)

\begin{tabular}{l|cc|cc|cc|}
\hline & \multicolumn{2}{|c|}{$\mathbf{1 9 5 6 - 6 0}$} & \multicolumn{2}{c|}{$\mathbf{2}$ 1966-70 } & \multicolumn{2}{c|}{ 1976-80 } \\
& $\mathbf{s p}$ & $\mathbf{s u}$ & $\mathbf{s p}$ & $\mathbf{s u}$ & $\mathbf{s p}$ & su \\
\hline Auckland LIA & 85 & 56 & 83 & 54 & 90 & 62 \\
Northland LIA & 80 & 50 & 83 & 54 & 89 & 52 \\
\hline \multirow{2}{*}{ Difference (A-N) } & 5 & 6 & - & - & 1 & 10 \\
\hline
\end{tabular}

December ('spring') and 2) from 1 January to the end of season ('summer'). This approach attempts to isolate the effect of summer into the second part of each season.

Northland's loss relative to South Auckland has progressively changed from being both a 'spring' and 'summer' loss to now being virtually all a late lactation or 'summer' loss, Here-in lies the reason for Northland now being described as being prone to "droughts". Except that this loss now seems to occur every season -even the good ones!

What then, has happened to Northland? 


\section{THE PASTURES}

Northland's pastures have undergone some dramatic changes in the last 15 to 20 years. Hedley (1967) in a paper to the last Grasslands Conference in Northland said: "During the nine months of the dairying season.. paspalum will comprise over half the species present". Similarly, du Faur (1962) wrote: "For example, although Northland, with its paspalum dominant pasture species . .. These writers were talking about pastures that were completely different to the Northland pastures of today. Paspalum these days, is almost insignificant in most dairy pastures having all but disappeared completely in the early 1970's but recovering slowly in more recent times.

Of great significance in this pasture change was a population explosion of black beetles (Reynolds and Langton 1973) in association with a sequence of dry summers. This combination appears to have been disastrous for the paspalum component of the dairy pastures of the day.

The devastation of the pastures created a widespread need for resowing. However, field observation would suggest that relatively little resowing was carried out. The major reason for this being the financial constraints resulting from the drought. As a result most pastures were left to recover by natural reseeding. Any resowing was with less persistent and productive cultivars. The newer cultivars, Nui and Ellett were just on the horizon at that time. Could this be a major cause of Northland's apparent summer problem and loss in production relative to South Auckland?

\section{THE IMPLICATIONS}

This period of change in pasture composition, the effects on stock plus the subsequent management stress, created an interest in conserved forage and cropping systems (Taylor et al 1979). Their conclusions, plus field observation show that forage cropping has failed to gain acceptance as a satisfactory solution to Northland's "summer problem". Cost, management complications and variable yields would be the major discouragements. However, pasture silage systems have found quite wide acceptance.

Silage has the immediate advantage that it is further utilising the established perennial pastures. There are no cultivation skills required, nor major management complications. It has advantages over hay in terms of cost, less weather dependence (therefore better quality?) and ease of mechanisation. But perhaps even more advantageous is that silage can be made earlier in the season, thus giving paddocks the chance to recover before the onset of dry weather conditions (Rogers and Robinson 1981).

The role of silage and the need for a summer supplement has been questioned at length (Bryant 1983). However, field experience in Northland would suggest that most farmers prefer the security of having some supplement. At high stocking rates the availability of a pasture surplus to conserve can be variable. Fortunately, under Northland conditions nitrogen can provide a good boost to a small surplus to help create an economic reserve of silage (Taylor et al 1979). All this assumes of course, that suitable equipment is available and can be got onto the paddocks when necessary. Not always easy!

\section{THE SOILS}

Northland's soils are well known for their particular characteristics. Mention must be made of the need for good drainage if Northland's "summer problem" is to be solved. Drainage not only improves utilisation and growth in the winter, but also in other seasons including the summer (Duigan and Page 1983, J. Walst pers. comm.). Drainage also helps reduce pasture damage (pugging) and facilitates the use of machinery, especially in the winter and spring. 


\section{THE SOLUTION}

Farmers identified by Northland's "Dairy Farmer of the Year" competition have consistently produced at very high levels despite significant seasonal weather variations. Stocking rates are generally well above surrounding farms. All these farms are producing at levels that only 10 to 15 years ago would have been considered almost impossible in Northland. These farmers are Northland's innovators and have shown not only what can be done but have provided the motivation to others to try to do even better. Northland has no "peculiar" problems, they are just challenges to management!

Like most other dairyingareas throughout New Zealand, Northland will experience dry summers. However, good management can minimise the effects of these periods. Some of the successful principles demonstrated by top Northland farmers are:

1. Establish and maintain highly productive and persistent pastures using the best available cultivars.

2. Create soil conditions to maximise year-round pasture growth and utilisation, without damage. On many of Northland's soils this will require some degree of drainage.

3. Establish and maintain a high genetic merit (BI) herd to fully utilise pasture grown and to "keep milking" under all seasonal conditions.

4. Maximise the number of lactation days pre-summer by maintaining a high stocking rate and appropriate calving date and pattern.

5. Manage pastures to achieve maximum growth in each season of the year.

6. Identify any pasture surplus early and boost with nitrogen if necessary, to create an economic reserve of silage.

7. In a dry summer, feed silage to avoid excessive weight loss in the stock and prevent over-grazing of pastures.

8. Use good management in all seasons to maximise financial returns and build a sound financial base from which to weather the repercussions of a "bad season".

Are these principles really any different to those that would apply in most other dairying districts?

\section{References}

Bryant, A.M. 1983. "Dairy Cattle Management" AgLink FPP 163

Coulter, J.D. 1965. N.Z. Geographer 22: 22-34.

de Lisle, J.F.; Kerr I.S. 1964. Misc. Pub. 115(2) N.Z. Met. Service

du Faur R. 1962. "Dairy Farming for Profit" P.80.

Duigan, B.; Page, C. 1983. "Benefits of Sub-surface Drainage" Unpub. Paper to Kaikawa Farmers Conf. Hedley, B.R. 1967. Proc. N.Z. Grassld. Ass. 29: 47.

M.A.F. 1980. "National Agriculture" AgLink NZA 64.

Male, A.J.R. 1978. Northland Regional Resources Survey. 387-425.

Martin, G.N.; Waugh, J.R. 1971. "An Assessment of Drought from Rainfall Data". MWD Whangarei, Cyclo $13 p$.

N.Z. Dairy Board Farm Production Reports Nos 36.60

Reynolds, D.G.; Langton, A.C.F. 1973. Proc. N.Z. Weed Pest Con/ Conf. 26: 182-183.

Rogers, G.; Robinson, I. 1981. Dairy Production Res. Report, Vic. Dept of Ag. p.47.

Scott, J.D.J. 1980. "Production in the Summer" AgLink FPP. 161

Taylor, A.O.; Hunt, B.J.; Hart, N.D.; Guest, J.; Walker, A.B.; Harris, H. 1979. "The Testing of Forage Systems on Northland Dairy Farms". Technical Report NO. 7, Plant Physiology Division, DSIR P59-63 